\title{
Response of in vitro reared honey bee larvae to various doses of Paenibacillus larvae larvae spores
}

\author{
Camilla J. Brødsgaard ${ }^{\mathrm{a} *}$, Wolfgang Ritter ${ }^{\mathrm{b}}$, Henrik Hansen ${ }^{\mathrm{a}}$ \\ a Danish Institute of Agricultural Sciences, Research Group Entomology, \\ Research Centre Flakkebjerg, DK-4200 Slagelse, Denmark \\ b Tierhygienisches Institut, Abteilung Bienenkunde, 79 018, Freiburg, Germany
}

(Reccived 19 December 1997; accepted 27 May 1998)

\begin{abstract}
The relationship between the number of Paenibacillus larvae larvae spores fed individually to 24-28, 48-52 and 72-76 h old Apis mellifera ligustica larvae and the number of larvae dying from the $P$. l. larvae infection was investigated as well as the effect of sublethal infection with $P$. I. larvae on larval development time and adult weight. The larvae were laboratory reared, thus, excluding the influence of nurse bees. The results show that larvae $24-28 \mathrm{~h}$ old are most susceptible to infection with $P$. l. larvae with a clear dose-response relationship $\left(\mathrm{LD}_{50}=8.49\right)$. Older larvae become more and more resistant to infection with $P$. l. larvae so that no significant dose-mortality relationship exists in the 48-52 and 72-76 h age groups. Furthermore, a significant negative correlation exists between the development time and emergence weight for the adult bees in both the non-inoculated group and the inoculated group. There was no difference in development time between non-inoculated larvae and those that survived the inoculation. (1) Inra/DIB/AGIB/Elsevier, Paris
\end{abstract}

Apis mellifera ligustica / American foulbrood / Paenibacillus larvae larvae / $\mathrm{LD}_{50}$ / in vitro rearing

\section{INTRODUCTION}

Paenibacillus larvae larvae is the causative agent of American foulbrood in honey bees (Apis mellifera L.). This disease is lethal to honey bee colonies if curative control actions are not taken [10]. In the late 1930 s, Woodrow $[30,31]$ studied the sus- ceptibility of honey bee larvae to P. l. larvae, by individual inoculation of spores in larval food. He demonstrated an effect of age on susceptibility showing that larvae younger than $24 \mathrm{~h}$ are the most susceptible. Using the results of Woodrow [31] on larvae approximately 24 h old, Bucher [3] adapted the data to log-probit analysis and found the

\footnotetext{
* Correspondence and reprints

E-mail: camilla.brodsgaard@agrsci.dk
} 
median lethal dose $\left(\mathrm{LD}_{50}\right)$ to be 35 spores of $P$. l. larvae with a regression slope of 0.82 .

The susceptibility of honey bee larvae has been further studied $[2,13,16,23]$ and shown to be associated with the genetic constitution of the bees. In these studies and in the studies of Woodrow [30, 31] the inoculated larvae were nursed by the bees in the colonies. By using this procedure the nurse bees probably influenced the dose-mortality relationship.

Woodrow [31] assumed that inoculation of the larvae was responsible for most of the observed removal by nurse bees. Nurse bees may remove inoculated larvae that would otherwise have survived inoculation leading to an underestimation of the LD figures. On the other hand, Sturtevant and Revell [27] report that nurse bees filter the spores fed to the larvae by action of the proventriculus. To some extent this ability prevents spore contamination of the food fed to the larvae leading to an overestimation of the LD figures.

The present study has been carried out in an attempt to elucidate: 1) the relationship between the number of spores fed to individual larvae in three distinctive age classes of a certain bee strain and the number of larvae dying from $P$. l. larvae infection; and 2) larval development time and adult emergence weight in larvae surviving the inoculation with $P$. l. larvae was investigated. Contrary to previous studies, the larvae in the present experiment were laboratory reared. In this way it was possible to exclude the influence of nurse bees to obtain a more precise picture of the dose-mortality relationship in individual larvae.

\section{MATERIALS AND METHODS}

\subsection{Larval material}

The test larvae originated from colonies with sister queens, which were descendants of a line bred on a Danish island. Average cubital index and genetic analysis showed that the line was
Apis mellifera ligustica Spinola [14, 28]. The queens were mated on an island with a known line of drones. The colonies were naturally noninfested with varroa mites (Varroa jacobsoni Oudemans) and had never been treated with acaricides. The colonies were examined for infection with the following honey bee viruses: acute paralysis virus, deformed wing virus and sackbrood virus by immuno diffusion [17] and found to be negative. Furthermore, the colonies were checked for clinical symptoms of $P$. I. larvae according to White [29] and honey samples were analysed according to Hansen [9] and the colonies were found to be negative.

The larvae were obtained by caging the queens for $4 \mathrm{~h}$ periods on broodless combs in the colonies. When the larvae reached the age of $24-28,48-52$ or $72-76 \mathrm{~h}$, they were reared in the laboratory. During the experiments, samples of larvae were taken regularly at the time as the initial grafting. These larvae were rinsed in sterile physiological saline, dried off and weighed. The larvae were not used again in the experiment.

\subsection{In vitro rearing of larvae}

The larvae were grafted into artificial cells as described by Rembold and Lackner [20] in a moist ( $\mathrm{RH}>95 \%$ ) glass chamber accessible from two sides at $35^{\circ} \mathrm{C}$ [32]. The chamber was modified with an anti-dew device that was developed to enable us to graft using a stereo microscope and the plane of the chamber. Thereafter, the larvae were reared by the technique described by Rembold and Lackner [20] with the modification that on the 4th rcaring day the larvae were grafted into new artificial cells ( $R$. Reiche, pers. comm.) using a spatula with a $25 \times 40 \mathrm{~mm}$ blade made of light-alloy metal developed by us. An incubator with precise regulation of humidity and temperature (Biomed $\mathrm{CO}_{2}$ incubator, ASSAB Classic T305 GF) was used for the rearing.

Prior to using royal jelly ( $100 \%$ pure, purchased from Werner Seip, Biologische Produkte, D-35510 Butzbach-Ebergöns) in the larval food mixture as described by Rembold and Lackner [20], it was checked for $P$. I. larvae by culturing using the honey routine diagnosis method [9] and found to be negative. According to our observations confirmed by R. Reiche (pers. comm.) methyl-4-hydroxybenzoate (normally added to the larval food to prevent fungal con- 
tamination [12]) prevents $P$. l. larvae from germinating. Consequently, methyl-4-hydroxybenzoate was not added to the larval food. Instead, demineralized water containing $0.015 \%$ methyl4-hydroxybenzoate was used in the evaporation chamber of the incubator. In the first two repetitions the larvae were reared until emergence. Thereafter, the experiment was stopped 14 days after inoculation.

\subsection{Inoculation of larvae}

Immediately after the initial grafting $2 \mu \mathrm{L}$ of a $P$. l. larvae spore solution was applied by a micropipette to the mouth parts of each larva under stereo microscopy $(\times 15)$.

The spores originated from foulbrood scales containing spores of a Danish P. l. larvae strain, JT-79, characterized by morphology of colonies [11], microscopy of Gram stained cells, phase contrast microscopy of spores, catalase activity [8], an API $50 \mathrm{CH} \beta$ technique described by Carpana et al. [4] and fatty acid analysis [6]. The scales were suspended in sterile physiological saline. The spore suspension was cultured on J-agar prepared as described by Gordon et al. [8]. The sporulating colonies were harvested in sterile physiological saline. Dilutions of this stock were made and the spore concentration determined by counting in Thoma blood cell chambers by means of phase contrast microscopy [5].These counts were repeated at least four times until the S.E.M. did not exceed $5 \%$. The spore concentrations in the dilutions were calculated on the basis of the mean value of the counts.

Eleven doses $(3,6,12,18,24,36,48,96$, $192,768,1384$ ) of spores were fed to $24-28 \mathrm{~h}$ old larvae. Twelve doses $(29,117,469,1875$, $6000,7500,15000,30000,60000,120000$, 240000,480000 ) of spores were fed to $48-52 \mathrm{~h}$ old larvae and six doses (1 500, 3000,150000 , $\left.300000,1.5 \times 10^{6}, 3 \times 10^{6}\right)$ of spores were fed to $72-76 \mathrm{~h}$ old larvae. The total number of $24-28 \mathrm{~h}$, $48-52 \mathrm{~h}$ and $72-76 \mathrm{~h}$ old larvae were 804,580 and 150 , respectively. In total 220 larvae that were fed $2 \mu \mathrm{L}$ physiological saline served as controls. The inoculation of larvae took place from late May to mid July.

The data of the trial runs were pooled before analysis. The results were analysed statistically by means of probit analysis [7]. Raw data were $\ln$ transformed and fitted to a normal distribution [24]. Abbott's correction formula [1] was applied to the data analysis before data were pooled.
Furthermore, spores from in vitro infected and diseased larvae were isolated, determined as described above for $P$. $l$. larvae, re-used for in vitro infection [15], re-isolated from diseased larvae and determined anew as for P. l. larvae [26] to fulfil Koch's postulates.

In the first two repetitions the age at the time of adult emergence was recorded in surviving inoculated and control bees. After emergence, the adults were weighed to test for a relationship between the time of emergence and weight of adult bees and the influence of non-lethal dose on this relationship. In the age group 48-52 $\mathrm{h}$ the time of emergence/weight relationship was determined for 35 control larvae and for 71 larvae fed with spore doses from 117 to 60000 . In the age group of $72-76 \mathrm{~h}$ the relationship was determined for 21 control larvae and for 72 larvae receiving all doses described for the dose-response investigation.

\section{RESULTS}

The mean weight of the larvae at first grafting in the different age groups is shown in table $I$. The larval weight increases significantly from the youngest to the oldest larvae. For larvae $24-28 \mathrm{~h}$ old the mean weight between sampling dates and between colonies did not differ significantly (Kruskal-Wallis, $P>0.05$ [25]).

The results of the first two repetitions of the three age groups with 215 larvae in total (24-28 h: 33 larvae, 48-52 h: 97 larvae, 72-76 h: 85 larvae) showed that no pupae developed symptoms of AFB later than day

Table I. Mcan weight ( \pm S.E.M.) of larvae at the initial grafting in the different age groups. There was a significant age group effect (Kruskal-Wallis [25] $P<0.0001$ ).

\begin{tabular}{lrr}
\hline Age $(\mathrm{h})$ & \multicolumn{2}{c}{ Number of larvae } \\
\hline $24-28$ & 78 & $0.724 \pm 0.0310 *)$ \\
$48-52$ & 37 & $2.424 \pm 0.0994 *)$ \\
$72-76$ & 40 & $\left.14.51 \pm 0.6117^{*}\right)$
\end{tabular}

* The results were tested by Kruskal-Wallis [25] and differed significantly from each other $(P<0.0001)$. 
14 after inoculation in any of the age groups. Koch's postulates were fulfilled. The control mortality ranged from 0.0 to $10.0 \%$ with a mean of $5.7 \pm 1.3 \%$.

In the control group, the bees emerged from days 13 to 19 when the rearing started at a larval age of 48-52 $\mathrm{h}$ and from days 15 to 18 when the rearing started at a larval age of 72-76 h. In the inoculated $48-52 \mathrm{~h}$ group, the bees emerged from days 13 to 19 and in the inoculated $72-76 \mathrm{~h}$ group, the bees emerged in the period from days 13 to 18 . The weight and age of emerged adults did not differ significantly $\left(\chi^{2}, P>0.05\right)$ between inoculation doses within each age group. Therefore, the data of the adult bees from the inoculated group were pooled and compared to control bees.

In the 48-52 h group, the results show a significant negative correlation between age and weight for the adult bees in the control group $\left(P<0.0001, \mathrm{r}^{2}=0.72\right)$ and for adults from the inoculated group $(P<0.0001$, $\mathrm{r}^{2}=0.63$ ) with no significant difference between the control and the inoculated groups (figure 1 ). In the $72-76 \mathrm{~h}$ group the age/weight relationship had a similar but not significant tendency.

In the control group of the 48-52 $\mathrm{h}$ age class, the bees emerging on day $13(n=5)$ had a significantly higher weight (KruskalWallis, $P<0.001$ ) than the bees emerging on days $14-15(n=9)$ and days $16-19(n=21)$, respectively. In the inoculated group, the bees emerging on day $13(n=4)$ differed significantly (Kruskal-Wallis, $P<0.001$ ) from the rest $(n=67)$. The distribution frequencies of emergence among bees from the control and the inoculated groups on the various days of emergence did not differ.

In the 24-28 $\mathrm{h}$ age group the dose-mortality data significantly fitted the probit model $\left(\chi^{2}, P>0.1\right)$. The dose-mortality relationship is shown in figure 2 . The $\mathrm{LD}_{50}$ was 8.49 (7.00-9.97 [95\% FL]) spores and the slope was 1.64. No significant dose-mortality relationship existed in the $48-52 \mathrm{~h}$ and $72-76 \mathrm{~h}$ age group (figures 3 and 4 ), and

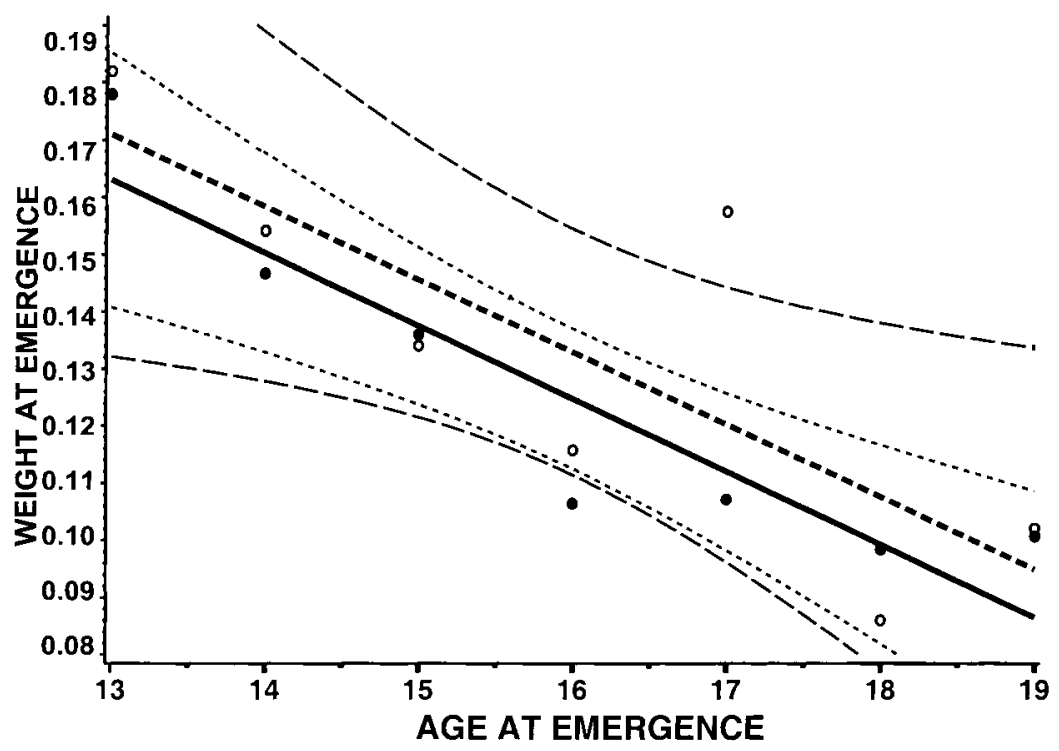

Figure 1. Mean emergence weight of bees in the $48-52 \mathrm{~h}$ group in relation to age of emergence. Dots and solid line indicate control bees, thin stippled curves indicate $95 \%$ c.l. Circles and bold broken line indicate inoculated bees, thin dashed curves indicate $95 \% \mathrm{c} .1$. 


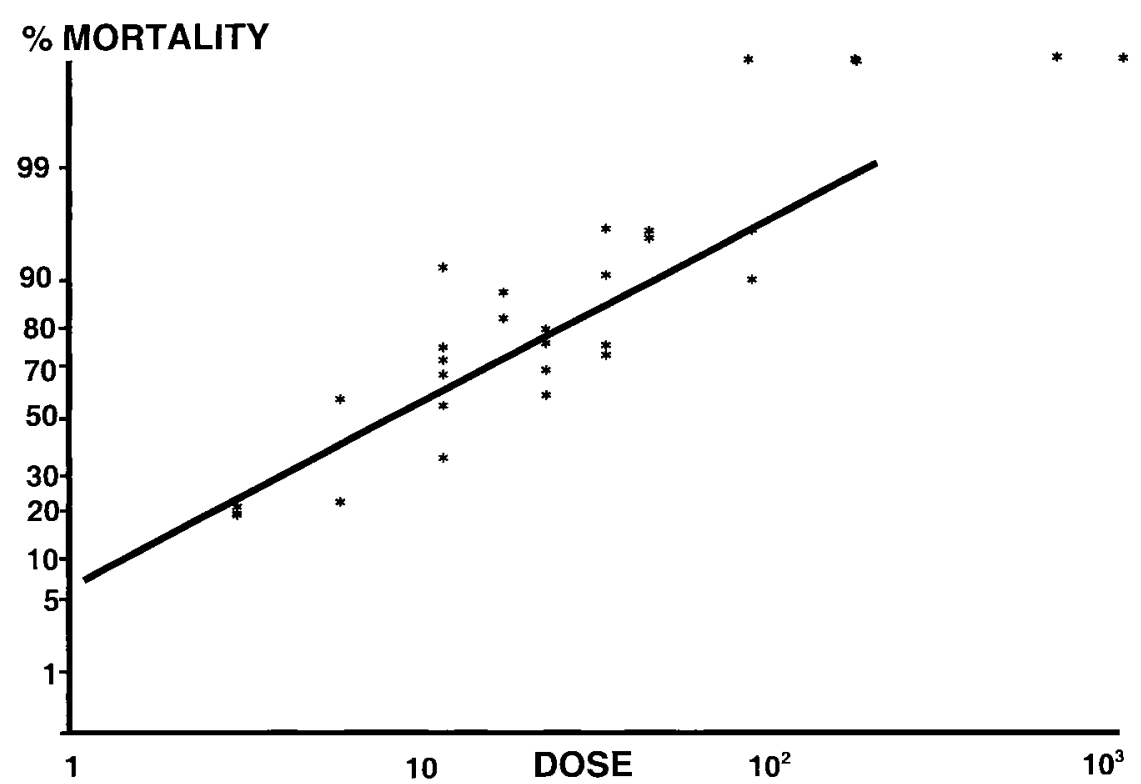

Figure 2. Dosage-mortality relationship for honeybee larvae infected at the age of $24-28 \mathrm{~h}$. Asterisks indicate percentage mortality per trial run $(n=804)$.

thus no $\mathrm{LD}_{50}$ or slope could be ascertained from these data.

\section{DISCUSSION}

The initial larval weight observed in this experiment is within the range of weights reported by Rembold [19] for the different ages resulting in that the $24-28 \mathrm{~h}$ group was stage L2 $(20-42 \mathrm{~h})$, the $48-52 \mathrm{~h}$ group was L3 $(42-66 \mathrm{~h})$ and the $72-78 \mathrm{~h}$ group was L4 (66-98 h).

The weight of newly emerged adult bees in the $48-52 \mathrm{~h}$ age group related significantly to larval development time (figure 1 ). This negative weight/development time relationship is well described. According to Hanser [12] and Rembold [19] bees from in vitro rearing emerging on day 13 are exclusively queens, on days $14-15$ a portion of the emerging bees will still be queens but the majority are intermediates. On day 16 the bees are mainly intermediates and from day 17 mainly worker bees emerge. In addition, the present experiment suggests that sublethal infection with $P$. l. larvae does not change larval development time or adult weight (figure 1). According to Rembold [19] L4 larvae that are fed pollen will never develop into queens. As described above, the larvae in age group $72-78 \mathrm{~h}$ were already fed pollen in the colonies at the time of the grafting and, thus, predisposed to develop into workers before the onset of the in vitro rearing. Hence, all adults in that age group emerged later than days 13-14 regardless of the in vitro feeding.

The present experiments suggest that A. m. ligustica larvae are very susceptible to AFB if second larval instar are infected with $P$. l. larvae, i.e. before $48 \mathrm{~h}$ after egg hatching. For 24-28 h old larvae (L2) only 8.49 (7.00-9.97 [95\% FL]) spores fed per larva will kill $50 \%$ and $\mathrm{LD}_{90}$ is only 51.35 (41.53-67.62 [95 \% FL]) spores. Moreover, our experiments suggest that an intrinsic 


\section{\% MORTALITY}

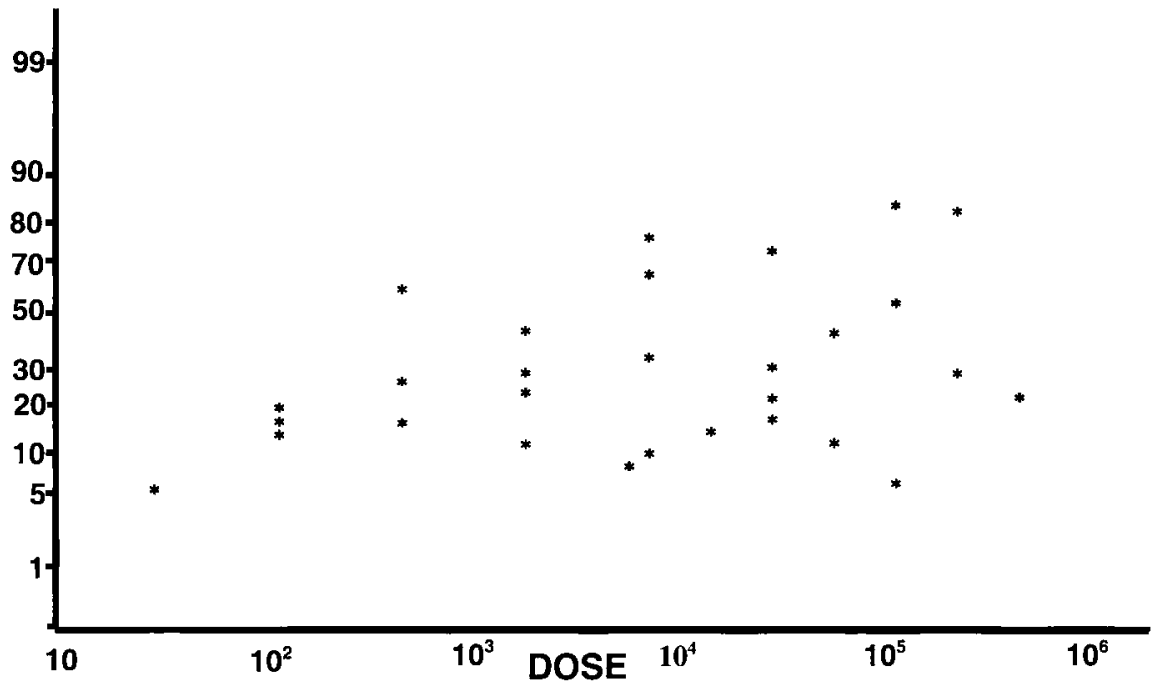

Figure 3. Dosage-mortality relationship for honeybee larvae infected at the age of $48-52 \mathrm{~h}$. Asterisks indicate percentage mortality per trial run $(n=580)$.

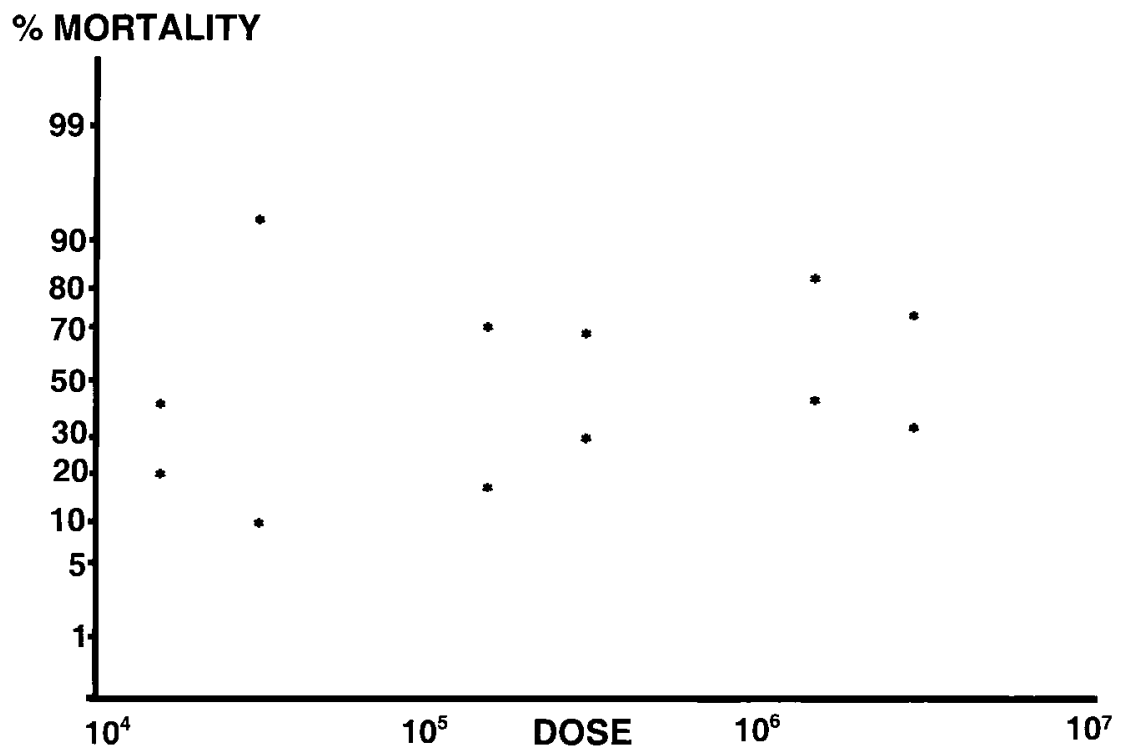

Figure 4. Dosage-mortality relationship for honeybee larvae infected at the age of $72-76 \mathrm{~h}$. Dots indicate percentage mortality per trial run $(n=150)$. 
resistance to $\mathrm{AFB}$ develops as the larvae mature confirming the results of Bamrick and Rothenbuhler [2]. Bucher [3], using the data of Woodrow [31], calculated an $\mathrm{LD}_{50}$ of 35 spores per larva with a slope of 0.82 . In the experiments of Woodrow, nurse bees in colonies tended the larvae and he reported that these bees removed a substantial number of larvae. Bucher [3] does not mention in which way these removed larvae were included in his calculation of the $\mathrm{LD}_{50}$. We have re-calculated the data of Woodrow [31] by means of a $\log$-probit analysis and regarded both removed larvae and larvae which showed clinical symptoms in the sealed cells as dead from infection with $P$. l. larvae. As the control mortality was low $(8.8 \%)$ Abbott's [1] normal correction was applied to the data. The $\mathrm{LD}_{50}$ from this calculation is 21.87 (8.70-51.12 [95\% FL]) spores and the slope is 0.44 , which is much higher than suggested in our study. Sturtevant and Revell [27] report that nurse bees filter spores fed to the larvae by action of the proventriculus and that this ability to some extent prevents spore contamination of the food fed to the larvae. This is probably a major reason for the differences in the $\mathrm{LD}_{50}$ values between our experiment and Woodrow's [31], as nurse bees were not present in our experiment. Furthermore, in Woodrow's [31] experiment, the queens were caged for $24 \mathrm{~h}$ resulting in experimental larvae that were 1-2 days old at point of infection. Thus, an unknown fraction of the larvae in Woodrow's youngest age group were actually closer to our $48-52 \mathrm{~h}$ age group than to our 24-28 $\mathrm{h}$ group. This could probably also contribute to the higher $\mathrm{LD}_{50}$ value in Woodrow's experiment compared to ours, as it has been demonstrated by the present experiment and by Bamrick and Rothenbuhler [2] that the larvae become more resistant to AFB as they mature. Another additional explanation could be a difference in innate larval tolerance between the bee strains used.

Hoage and Rothenbuhler [13] found that larvae at an age of $18-24 \mathrm{~h}$ at inoculation in a 'susceptible' bee line had an $\mathrm{LD}_{50}$ of 1300 spores with a slope of 0.663 and for a resistant line an $\mathrm{LD}_{50}$ of 2500 spores with a slope of 0.496. In Hoage and Rothenbuhler's [13] experiment the number of missing larvae (removed by nurse bees) were added to the number of larvae dead from AFB to give the percentage of non-survival. The $\mathrm{LD}_{50}$ values were calculated on that combined data.

Many of the larvae in the 48-52 and $72-76 \mathrm{~h}$ age group in our experiment had apparently attained sufficient resistance to resist infection at all dosage levels so that no clear dose-mortality tendency appeared. These results correspond with the findings of Hoage and Rothenbuhler [13] as they, too, were unable to find a clear dosage-response relationship using larvae at ages of $36-42 \mathrm{~h}$ nursed by bees in colonies. Besides the intrinsic resistance to AFB in older larvae, an induced resistance probably also acts in vivo in larvae older than 3-4 days because the laval diet thereafter contains pollen [21]. Pollen contains microorganisms which act as antagonists of $P$. $l$. larvae preventing the germination of spores in vitro. This might also be the case in the intestine of the larvae [18]. This hypothesis is supported by the findings of Rinderer et al. [22] as they have shown that feeding pollen to larvae 6-18 h old can significantly reduce the mortality in experimentally infected larvae.

The present study shows that 24-28 h old larvae are very susceptible to infection with $P$. l. larvae with a clear dose-response relationship. Thereafter, the larvae become more and more resistant to infection with $P$. l. larvae due to intrinsic factors. The results obtained by using the in vitro rearing technique suggest that the nurse bees used in similar experiments might have influenced the observed dose-mortality relationship of the larvae. The in vitro rearing method is an important tool for examination of larval diseases as the influence from nurse bees (that can include removing larvae and spores and not feeding the larvae equally) can be 
excluded. The method could be used for testing of larval disease tolerance among different bee strains. Such in vitro tests, combined with tests of removal behaviour in small experimental hives, can be concluded in only 1-2 months and give more information than a test in full scale bee colonies that takes several years and is much more expensive [10].

\section{ACKNOWLEDGEMENTS}

We thank L. Hasmark, S. Metzinger and A. Marthin for their technical help and H.F. Brødsgaard for critical comments on the manuscript. We are grateful to S.W. Omholt, A. Hagen and S. Rishovd (Agricultural University of Norway, Department of Animal Science, Ass, Norway) and E.J. Hentschel, R. Reiche and E. Woker (Friedrich-Schiller-Universität, Ernährung und Umwelt, Bienenkunde, Jena, Germany) for discussing the in vitro rearing technique with us.

Résumé - Sensibilité des larves d'abeilles élevées in vitro à diverses doses de spores de Paenibacillus larvae larvae. Le but de l'étude était de mieux comprendre la relation entre la quantité de spores de $P$. l. larvae, administrées individuellement à des larves d'Apis mellifera ligustica réparties en trois classes d'âge, et le nombre de larves mortes d'infection. En outre la durée du développement postembryonnaire et le poids de l'adulte à l'émergence ont été étudiés chez des larves âgées de 48-52 et de 72-76 h qui avaient survécu à l'infection par $P . l$. larvae. Contrairement au études précédentes, les larves ont été élevées au laboratoire. Il était ainsi possible d'exclure l'influence des nourrices et d'avoir une image plus précise de la relation dose-réponse chez les larves prises individuellement. Onze doses différentes de spores ont été administrées aux larves âgées de 24-28 h $(\mathrm{N}=804)$, douze aux larves âgées de 48-52 h $(\mathrm{N}=580)$ et six à celles âgées de $72-76 \mathrm{~h}(\mathrm{~N}=150)$. Comme témoin on a utilisé 220 larves non infectées. Les résultats montrent que les larves de 24-28 h sont les plus sensibles à l'infection $\operatorname{par} P$. l. larvae et qu'il existe une relation dose-réponse avec une $\operatorname{LD50}=8.49$ (7.00-9.97 [95\% FL]) et une pente de 1.64 (figure 2). Par la suite les larves deviennent de plus en plus résistantes à l'infection, si bien qu'il n'y a plus de relation dose-mortalité chez les larves de 48-52 h et de 72-76 h (figures 3 et 4 ). Le tableau I donne le poids moyen des larves au premier greffage pour les divers groupes d'âge. Le poids des larves augmente significativement de la plus jeune à la plus âgée. Les résultats montrent en outre que dans le groupe 48-52 h il existe une correlation négative significative entre l'âge et le poids à l'émergence, aussi bien dans le groupe témoin que dans le groupe infecté (figure 1). Dans le groupe $72-76 \mathrm{~h} \mathrm{la}$ relation présente la même tendance mais n'est pas significative. Les fréquences de distribution de l'émergence aux divers jours d'émergence ne varie pas entre les abeilles du groupe témoin et celles du groupe infecté. (C) Inra/DIB/AGIB/Elsevier, Paris

\section{Apis mellifera / loque américaine / Paenibacillus larvae larvae / $\mathrm{DL}_{50}$ / élevage in vitro / effet âge}

\section{Zusammenfassung - Die Anfälligkeit von} in vitro aufgezogenen Bienenlarven gegenüber Sporen von Paenibacillus larvae larvae in unterschiedlichen Dosierungen. Die Beziehung zwischen unterschiedlichen Mengen verfütterter Sporen von Paenibacillus larvae larvae an einzelne Larven von Apis mellifera ligustica und dem Tod der Larven durch die Infektion sollte aufgeklärt werden. Hierbei wurden unterschiedliche Dosierungen der Sporen und drei unterschiedliche Altersklassen untersucht. Darüber hinaus wurde die Entwicklungszeit der Larven bis zum Schlupf der Adulten und deren Gewicht untersucht, sofern diese die Infektion mit $P$. l. larvae im Alter von $48-52 \mathrm{~h}$ bzw. 72-76 h überlebt hatten. Im Gegensatz zu früheren Studien, wurden die in diesem Experiment verwen- 
deten Larven im Labor aufgezogen. Hierdurch konnte der Einflu $\beta$ von Ammenbienen ausgeschlossen und ein genaueres Bild der Dosis- Effektbeziehung individueller Larven gewonnen werden. Die Sporen wurden an 24-28 $\mathrm{h}$ alte Larven $(\mathrm{N}=804)$ in elf Dosierungen, an $48-52 \mathrm{~h}$ alte Larven $(\mathrm{N}=$ 580 ) in 12 Dosierungen, und an $72-76 \mathrm{~h}$ alte Larven $(\mathrm{N}=150)$ in sechs Dosierungen verfüttert. Als Kontrollen dienten 220 Larven, die nicht infiziert wurden. Die Ergebnisse zeigen, da $\beta$ 24-28 h alte Larven am anfälligsten gegenüber einer Infektion mit $P$. $l$. larvae sind, wobei eine klare Dosis-Effektbeziehung mit $\mathrm{LD}_{50}=8.49$ (7.00-9.97 [95\% FL]) Sporen und einer Steigung von $1.64(A b b . I)$ besteht. Später wurden die Larven immer resistenter gegenüber der Infektion mit $P$. l. larvae, so $\mathrm{da} \beta$ in den Altersgruppen von $48-52 \mathrm{~h}$ und 72-76 h keine signifikante Dosis-Effektbeziehung mehr bestand ( $A b b .3$ und 4 ). Das mittlere Gewicht der Larven in den unterschiedlichen Altersgruppen bei der ersten Umlarvung ist in Tabelle I dargestellt. Von den jüngsten zu den ältesten Larven nimmt das Larvengewicht signifikant zu. Weiterhin zeigen die Ergebnisse, da $\beta$ in der 48-52 h Gruppe das Alter und das Gewicht der schlüpfenden Bienen sowohl bei den infizierten als auch bei den nichtinfizierten Bienen signifikant negativ korreliert waren $(A b b . I)$. In der 72-76 h Gruppe bestand eine ähnliche Tendenz, die aber nicht sicherbar war. Die Häufigkeitsverteilungen des Schlupfs an den verschiedenen Schlupftagen unterschied sich nicht zwischen infizierten und nichtinfizierten Larven. (C) Inra/DIB/AGIB/Elsevier, Paris

\section{Apis mellifera ligustica / Amerikanische Faulbrut / Paenibacillus larvae larvae / $\mathbf{L D}_{50}$ / in vitro-Aufzucht}

\section{REFERENCES}

[1] Abbott W.S., A method of computing the effectiveness of an insecticide, J. Econ. Entomol. 18 (1925) 265-267.
[2] Bamrick J.F., Rothenbuhler W.C., Resistance to American foulbrood in honey bees, IV. The relationship between larval age at inoculation and mortality in a resistant and in a susceptible line, J. Insect Pathol. 3 (1961) 381-390.

[3] Bucher G.E., General summary and review of utilization of disease to control insects, Proc. I0th Int. Congress of Entomology 4 (1958) 695-701.

[4] Carpana E., Marocchi L., Gelmini L., Evaluation of the API 50CHB system for the identification and biochemical characterization of Bacillus larvae, Apidologie 26 (1995) 11-16.

[5] Drews G., Mikrobiologisches Praktikum, Springer-Verlag, Berlin, 1976.

[6] Drobníková V., Richter V., Häusler J., Pytelová I., Characterization of Bacillus larvae and related bacilli by chromatography of cell fatty acids, J. Apic. Res. 33 (1994) 69-74.

[7] Finney D.J., Probit Analysis, 3rd ed., Cambridge University Press, London, 1971.

[8] Gordon R.E., Haynes W.C., Pang C.H., The Genus Bacillus, USDA, Washington, 1973.

[9] Hansen H., Methods for determining the presence of the foulbrood bacterium Bacillus larvae in honey, Tidsskr. Planteavl 88 (1984) $325-328$.

[10] Hansen H., Brødsgaard C.J., Der Verlauf der Amerikanischen (Bösartigen) Faulbrut in künstlich infizierten Völkern, ADIZ/die Biene 3 (1997) 11-14.

[11] Hansen H., Rasmussen B., The investigation of honey from bee colonies for Bacillus larvae, Tidsskr. Planteavl 90 (1986) 81-86.

[12] Hanser G., Die Aufzucht von Bienenköniginnen im Labor, in: Ruttner F. (Ed.), Königinnenzucht, Apimondia-Verlag, Bukarest, 1980, pp. 45-64.

[13] Hoage T.R., Rothenbuhler W.C., Larval honey bee response to various doses of Bacillus larvae spores, J. Econ. Entomol. 59 ( 1966) 42-45.

[14] Itenov K., Skjøth F., Uniformity within race and genetic constitution of a population of the brown honcybee on the island of Læs $\emptyset$, SP-rapport 4, 1993, 35 p. (in Danish with English summary).

[15] Koch R., Die Aetiologie der Milzbrand-Kranheit, begrundet auf die Entwicklungsgesichte des Bacillus Anthracis, Beitrage zur Biologie der Planzen 2 (2) (1876) 277-310.

[16] Lewis L.F., Rothenbuhler W.C., Resistance to American foulbrood in honey bees: III. Differential survival of the two kinds of larvae from two drone matings, J. Insect. Pathol. 3 (1961) 197-215.

[17] Mansi W., Slide gel diffusion precipitin test, Nature 181 (1958) 1289-1290.

[18] Reiche R., Martin K., Möllmann U., Hentschel E.J., Beitrag zur Klärung der Resistenz der Bienenlarven gegen den Erreger der Amerikanischen Faulbrut Paenibacillus (voher Bacillus) larvae (White 1906), Apidologie 27 (1996) 296-297. 
[19] Rembold H., Die Aufklärung der Kastenentstehung im Bienenstaat, Mannheimer Forum 87/88 (1988) 168-231.

[20] Rembold H., Lackner B., Rearing of honeybee larvae in vitro: Effect of yeast extract on queen differentiation, J. Apic. Res. 20 (1981) 165-171.

[21] Rembold H., Lackner B., Geistbeck I., Chemical basis of honeybee, Apis mellifera, caste formation, partial purification of queen bee determinator from royal jelly, J. Insect Physiol. 20 (1974) 307-314.

[22] Rinderer T.E., Rothenbuhler W.C., The influence of pollen on the susceptibility of honeybee larvae to Bacillus larvae, J. Invertebr. Pathol. 23 (1974) 347-350.

[23] Rothenbuhler W.C., Thompson V.C., Resistance to American foulbrood in honey bees, I. Differential survival of larvae of different genetic lines, J. Econ. Entomol. 49 (1956) 470-475.

[24] SAS Institute Inc., SAS/STAT ${ }^{\circledR}$ User's guide ver. 6, 4th ed., SAS Institute, Cary, NC, 1990.

[25] Siegel S., Castellan N.J. Jr, Nonparametric Statistics, McGraw-Hill Book Co., Singapore, 1988.

[26] Smith E.F., Bacteria in relation to plant diseases, vol. 1, 1905.
[27] Sturtevant A.P., Revell I.L., Reduction of Bacillus larvae spores in liquid food of honey bees by action of the honey stopper, and its relation to to the development of American foulbrood, J. Econ. Entomol. 46 (1953) 855-860.

[28] Svendsen O., Bertelsen I., Meyer I.-L., Identification of the honeybee subspecies (Apis mellifera mellifera versus Apis mellifera ligustica) by cubital index on the island of Læs $\phi$, Denmark, Tidskr. Planteavl 96 (1992) 319-324 (in Danish with English summary).

[29] White G.F., American foulbrood, USDA, Bureau of Entomology, Bulletin 809, 1920 , pp. 1-54.

[30] Woodrow A.W., Gochnauer T.A., Susceptibility of honey bee larvae to American foulbrood, Glean. Bee Cult. 69 (1941) 148-151, 190.

[31] Woodrow A.W., Susceptibility of honey bee larvae to individual inoculations with spores of Bacillus larvae, J. Econ. Entomol. 35 (1942) 892-895.

[32] Yu R., Hagen A., Omholt S.W., Cryopreservation of totipotent nuclei from honeybee (Apis mellifera) embryos by rapid freezing, Cryobiology 35 (1997) 41-45. 